\title{
Screening of Bio-Surfactant Production Ability among Organic Pollutants Degrading Isolates Collected From Egyptian Environment
}

\author{
Mariam Hassan, Tamer Essam*, Aymen S Yassin and Aisha Salama
}

DMicrobiology and Immunology Department and Biotechnology Centre, Faculty of Pharmacy, Cairo University, Cairo, Egypt

\begin{abstract}
A total of ten bacterial isolates were screened for their biodegradation, metabolic versatility and biosurfactants production using various organic pollutants. The biosurfactants production ability was mainly assessed by oil spread test (OST) and/or emulsification assay (EA). Although initial biosurfactants screening was conducted using paraffin oil, the application of vegetable oils, particularly coconut oil, was always accompanied with the highest yield of biosurfactants production,. Biochemical and molecular identification of the ten isolates revealed that they belong to three genera; Klebsiella (6), Pseudomonas (3) and Citrobacter (1). Interestingly, four isolates (M2H2 1, M2H2 3, $\mathrm{M} 2 \mathrm{H} 28$ and $\mathrm{M} 2 \mathrm{H} 2$ 14), showed the highest biosurfactants production and therefore were further assessed using mixed carbon source (coconut oil in combination with one organic pollutant (phenol or cyclohexanol)). The addition of the coconut oil was essential for increased production of biosurfactant, while the use of organic pollutant as a sole carbon source was always accompanied with lower productivity. Isolates (M2H2 1 and M2H2 14), showed the highest phenol biodegradation capacities (the most toxic pollutant), and were tested for the dual effect of biodegradation combined with biosurfactant production. Isolates $\mathrm{M} 2 \mathrm{H} 21$ and $\mathrm{M} 2 \mathrm{H} 214$ tolerated phenol concentrations up to 1500 and $1300 \mathrm{mgl}^{-1}$, respectively, with no significant effect on biosurfactant activity. Adopting the induction regimen increased the phenol removal percentage from $2 \%$ to $66 \%$ and from $10 \%$ to $35 \%$ with isolates $\mathrm{M} 2 \mathrm{H} 21$ and $\mathrm{M} 2 \mathrm{H} 2$ 14 , respectively.
\end{abstract}

Keywords: Emulsification; Oil; Bioremediation; Phenol

\section{Introduction}

Bioremediation provides a high potential and cost efficient tool for the treatment of toxic pollutants in different environments $[1,2]$, however, it still facing several limitations [3]. These limitations include the response to fluctuation in the concentration and/or the content of pollutants load. For instance, increasing the concentration and/or the toxicity of the polluting compounds may inhibit the growth of the biodegrading species [4]. Consequently, this would lead to the failure of the whole bioremediation process. In addition, the hydrophobic property of many of these compounds severely limits the mass transfer during the biological degradation [5] leading to poor availability of these compounds to the microbial cells. In this sense, the addition of surfactants and/or biosurfactants has been regarded as a promising approach to increase the bioavailability as well as the biodegradation efficiency [6].

Biosurfactants have a direct effect through increasing the solubility and dispersion of the hydrocarbon, hence increasing its availability for the microbial cells. Besides, they may change the affinity between microbial cells and hydrocarbons by inducing rises in cell surface hydrophobicity $[7,8]$, thus improving the biodegradation efficiency. Interestingly, biosurfactants could have stimulating effects on enzyme activities or production by microorganisms through their effect in aiding enzyme release $[9,10]$ and increasing the enzyme stability through prevention of the enzyme denaturation during hydrolysis by desorbing them from substrate [11]. Hence, the use of microbial strains that would have dual effect (degradation of the pollutants and production of the biosurfactants) would have several advantages [12].

In comparison with synthetic surfactants, biosurfactants have many features which have made them gain an increased attention. Biosurfactants have advantages that include higher biodegradability, lower toxicity, lower cost, selectivity and specific activity at extreme temperatures, $\mathrm{pH}$ and salinity [13]. On the other hand, synthetic surfactants currently used are toxic and are hardly degraded by microorganisms causing damage to the environment [14].

In the present study, we aimed at screening, isolating and characterizing bacterial isolates with relevant dual biodegradation and biosurfactants production ability. The isolates were tested for biosurfactants production, biodegradation ability and for their possible dual property. The effect of using different carbon sources was investigated as well as their toxic effect on the most relevant isolates.

\section{Materials and Methods}

Unless otherwise specified, all experiments were conducted under aseptic conditions and in triplicate. The data values shown represent the mean \pm standard error of conducted replicates.

Enrichment, isolation and maintenance of degrading bacterial isolates

Screening, isolation and maintenance of all microbial cultures were conducted using a mineral salt medium (MSM) with composition as previously described [15]. Whenever necessary, the MSM was enriched with required concentration of the selected substrate (Table 1) and/or solidified with $2 \%$ (w/v) Nobel agar (Oxoid, USA). Bacterial strains were

*Corresponding author: Tamer Essam, Lecturer, Microbiology and Immunology Department and Biotechnology Centre, Faculty of Pharmacy, Cairo University, Kasr El-Aini Street, Cairo 11562, Egypt, Tel: 01005661976 (or) 02 33079348; E-mail: tamer.essam@yahoo.com

Received April 06, 2014; Accepted April 29, 2014; Published May 05, 2014

Citation: Hassan M, Essam T, Yassin AS, Salama A (2014) Screening of BioSurfactant Production Ability among Organic Pollutants Degrading Isolates Collected From Egyptian Environment. J Microb Biochem Technol 6: 195-201. doi:10.4172/1948-5948.1000143

Copyright: ( 2014 Hassan M, et al. This is an open-access article distributed under the terms of the Creative Commons Attribution License, which permits unrestricted use, distribution, and reproduction in any medium, provided the original author and source are credited 
Citation: Hassan M, Essam T, Yassin AS, Salama A (2014) Screening of Bio-Surfactant Production Ability among Organic Pollutants Degrading Isolates Collected From Egyptian Environment. J Microb Biochem Technol 6: 195-201. doi:10.4172/1948-5948.1000143

\begin{tabular}{|c|c|c|c|c|c|c|c|c|c|c|c|}
\hline \multicolumn{2}{|c|}{ Isolate } & $\begin{array}{l}3 \\
\text { N } \\
\text { T }\end{array}$ & 永 & $\begin{array}{l}3 \\
\text { N } \\
N\end{array}$ & $\begin{array}{l}3 \\
N \\
N \\
N\end{array}$ & $\begin{array}{l}3 \\
\text { N } \\
\text { N }\end{array}$ & $\begin{array}{l}3 \\
\text { N } \\
N\end{array}$ & $\begin{array}{l}3 \\
\text { N } \\
\text { N }\end{array}$ & $\begin{array}{l}3 \\
\text { N } \\
\text { N }\end{array}$ & $\begin{array}{l}3 \\
\text { N } \\
N\end{array}$ & $\begin{array}{l}3 \\
\text { N } \\
\text { N }\end{array}$ \\
\hline Substrate & Conc. ${ }^{*}\left(\mathrm{mgl}^{-1}\right)$ & \multicolumn{10}{|c|}{$(+)$ means growth, (-) means no growth } \\
\hline Hexane & 100 & + & + & - & - & - & + & - & + & - & - \\
\hline Decane & 100 & + & - & - & - & - & - & - & - & - & - \\
\hline Dodecane & 100 & - & - & - & - & - & - & - & - & - & - \\
\hline Hexadecane & 100 & + & + & + & + & + & + & + & + & + & + \\
\hline Benzene & 100 & + & + & + & + & + & + & + & + & + & + \\
\hline Toluene & 100 & - & - & - & - & - & - & + & + & - & + \\
\hline Xylene & 100 & - & + & + & + & + & - & - & - & + & + \\
\hline Pyridine & 100 & + & + & - & + & + & + & + & + & + & + \\
\hline Phenol & 200 & + & + & + & + & + & + & + & + & - & + \\
\hline Cresol & 100 & + & + & + & + & + & + & + & + & + & + \\
\hline Salicylate & 100 & + & + & + & + & - & - & - & - & - & - \\
\hline Naphthalene & 50 & - & - & - & - & - & - & - & - & - & - \\
\hline Cyclohexanol & 1000 & + & + & + & + & + & + & + & + & + & + \\
\hline
\end{tabular}

$\left(^{*}\right)$ The maximum tested concentration.

Table 1: The recorded biodegradation ability and metabolic versatility of the isolates against different organic pollutants and/or organic solvents.

isolated from several soil samples, collected from different locations in Giza and Cairo. Isolation was conducted as previously described [15] with incubation conditions of $28 \pm 2^{\circ} \mathrm{C}$ and agitation at $180 \mathrm{rpm}$.

\section{Morphological, physiological and molecular identification}

Morphological characterization and motility tests were done using light microscopy (Olympus, USA). Gram stain reaction was done using Difco Gram stain set according to the standard protocol and as previously described [16]. Biochemical characterization was done using API 20 NE or 20 E kit systems (bioMérieux, France) according to the manufacturer's instructions. The presence of oxidase was determined using a test strip (Microbiology Bactident Oxidase, Merck, Germany). Catalase activity was evaluated by transferring a loop of bacterial cells onto a microscope slide and adding a drop of $3 \%$ hydrogen peroxide solution [15].

Molecular identification was carried out using partial 16S rRNA sequence analysis $[15,17]$ using two universal primers $28 \mathrm{~F}$ (forward primer) 5'AGAGTTTGATCCTGGCTCAG-3' (positions 8-28) and 1512R (reverse primer) 5'ACGGCTACCTTGTTACGACT-3' (positions 1512-1493), (E.coli. numbering). The GenBank database (NCBI, USA) was then used to search for 16S rRNA sequence similarities.

\section{Biodegradation and metabolic versatility}

For each of the ten isolates, an aliquot of $5 \mathrm{ml}$ of the bacterial suspension (106-107 CFU ml-1) was used to inoculate flasks containing $100 \mathrm{ml}$ MSM supplemented with increasing pollutant concentrations (Table 1). The flasks were incubated for 3 and up to 28 days at $28 \pm 2^{\circ} \mathrm{C}$ in an incubator shaker at $180 \mathrm{rpm}$. Samples were periodically withdrawn and tested for growth and/or pollutant removal. A significant increase in the optical density at $600 \mathrm{~nm}$ was considered as positive growth [15]. Negative controls were conducted by using MSM with the pollutants and without inoculation or MSM inoculated with the isolate without organic carbon source.

\section{Screening of biosurfactant production ability of biodegrading isolates}

Biodegrading bacterial isolates were preliminarily screened for biosurfactant production using paraffin oil as substrate. Initially, the inoculum was prepared as previously described [15]. Aliquots of 100 $\mathrm{ml}$ MSM supplied with required concentration of substrate were placed in $250 \mathrm{ml}$ erlenmeyer flasks and were inoculated by $5 \%(\mathrm{v} / \mathrm{v})$ of each bacterial isolate. Flasks were incubated in incubator shaker at 180 $\mathrm{rpm}$ and $35 \pm 2^{\circ} \mathrm{C}$ for 6 days and samples were withdrawn at the last day for analysis. Different oils (olive oil, castor oil, bitter almond oil and coconut oil), organic solvents (hexane, benzene and xylene) and organic pollutants (cyclohexanol) were used in order to evaluate their effects on biosurfactant productivity. In all cases, the collected samples were centrifuged at $4500 \mathrm{~g}$ for $30 \mathrm{~min}$ prior to analysis.

\section{Investigation of the dual effect "biodegradation coupled with biosurfactant production"}

The most relevant four isolates were selected to study the dual effect (coupled biodegradation and biosurfactants production), using the following combinations in (\% w/v): coconut oil (2) + phenol $(0.01)$, coconut oil (2) + cyclohexanol (0.025), phenol (0.01) and cyclohexanol (0.025). The control was $2 \%(\mathrm{w} / \mathrm{v})$ of coconut oil. The isolates showing the highest recorded biosurfactant productivity and biodegradation capacities of phenol were further selected to investigate the dual effect; in the presence of increasing concentrations $\left(100-1700 \mathrm{mgl}^{-1}\right)$ of phenol 
Citation: Hassan M, Essam T, Yassin AS, Salama A (2014) Screening of Bio-Surfactant Production Ability among Organic Pollutants Degrading Isolates Collected From Egyptian Environment. J Microb Biochem Technol 6: 195-201. doi:10.4172/1948-5948.1000143

as a model of organic pollutant. Samples of $5 \mathrm{ml}$ were withdrawn for analysis at regular time intervals. Whenever necessary, an induction regimen (i.e. initial addition of low concentration of the pollutant) was conducted using $500 \mathrm{mg} \mathrm{l}^{-1}$ of phenol to establish enough biomass prior to the addition of more phenol and coconut oil.

\section{Analysis}

Oil spreading test (OST): A total of $50 \mathrm{ml}$ of distilled water were added to a Petri dish ( $150 \mathrm{~mm}$ diameter) followed by the addition of $20 \mu \mathrm{l}$ of oil (castor oil) on the water surface to form a thin oil layer. An amount of $10 \mu \mathrm{l}$ of culture supernatant was gently placed onto the center of the oil layer surface. The surfactant activity in the culture supernatant produces oil displacement, thus forming a clear zone in the oil layer. The diameter of the clear zone was measured and recorded. In preliminary screening, test results with zone diameters greater than 0.5 $\mathrm{cm}$ were classified as positive [1].

Emulsification assay: An aliquot of $3 \mathrm{ml}$ of the supernatant was vortexed with $0.5 \mathrm{ml}$ castor oil for $2 \mathrm{~min}$. The mixture was left undisturbed for $1 \mathrm{~h}$. at $28 \pm 3^{\circ} \mathrm{C}$ to separate aqueous and oil phases. The aqueous phase was collected and measured at $400 \mathrm{~nm}$ using spectrophotometer (T80 UV/Vis spectrophotometer, USA). The emulsification units (EU) were calculated according to the following equation [18].

\section{$\mathrm{EU} \mathrm{ml} \mathrm{l}^{-1}=$ absorbance at $400 \mathrm{~nm} \times$ dilution factor/0.01}

Blue agar plates method (CTAB agar plate method): The CTAB agar plate method was used as a qualitative assay for the detection of anionic surfactants. The blue agar plates were prepared by adding 0.2 g cetyltrimethylammonium bromide (CTAB) and $0.005 \mathrm{~g}$ methylene blue (MB), $15 \mathrm{~g}$ agar and $20 \mathrm{~g}$ glycerol as a substrate to $1 \mathrm{l}$ of the MSM [19]. Wells were cut in the agar plates [20], where $10 \mu \mathrm{l}$ of the inoculum were added. The plates were incubated for $48 \mathrm{~h}$ at $37^{\circ} \mathrm{C}$ and then stored in the refrigerator for at least $24 \mathrm{~h}$. Formation of colonies surrounded by dark blue halos indicated the production of anionic surfactants. Examination using UV transilluminator was used to light the plates for easier detection [21].

Phenol analysis: Analysis of phenol was conducted by HPLC-UV (Schimadzu 10A VP, USA), equipped with a Supelco LC-18 column with a detection limit of $1 \mathrm{mg} \mathrm{l}^{-1}$ as previously described [15].

Statistical analysis: The statistical analysis and graphical presentation of data was done using graphpad prism software (version 5.01).

\section{Results}

\section{Morphological, physiological and molecular identification}

Ten bacterial strains were isolated. Preliminary examination showed that they were all rod shaped bacteria with Gram negative reaction. Further identification of the isolates showed that all had positive catalase reaction. Only three isolates (M2H2 1, M2H2 14 and $\mathrm{M} 2 \mathrm{H} 2 \mathrm{15}$ ) were motile and had positive oxidase reaction (Table 3). Isolates $\mathrm{M} 2 \mathrm{H} 24, \mathrm{M} 2 \mathrm{H} 2 ~ 7, \mathrm{M} 2 \mathrm{H} 2 ~ 8, \mathrm{M} 2 \mathrm{H} 2 ~ 10, \mathrm{M} 2 \mathrm{H} 216$ and M2H2 18 were identified biochemically (using API 20E kit system) and molecularly and were shown to be members of Klebsiella spp. Isolate M2H2 3 was classified molecularly as a member of Citrobacter

\begin{tabular}{|c|c|c|c|c|c|c|c|}
\hline \multicolumn{2}{|c|}{ Substrates } & \multirow{2}{*}{$\begin{array}{l}\text { Paraffin } \\
\text { Oil } 2 \% \text { w/v }\end{array}$} & \multirow{2}{*}{$\begin{array}{c}\text { Olive } \\
\text { Oil } 2 \% \text { w/v }\end{array}$} & \multirow{2}{*}{$\begin{array}{c}\text { Castor } \\
\text { Oil } 2 \% \text { w/v }\end{array}$} & \multirow{2}{*}{$\begin{array}{l}\text { Bitter Almond } \\
\text { Oil } 2 \% \mathrm{w} / \mathrm{v}\end{array}$} & \multirow{2}{*}{$\begin{array}{l}\text { Coconut } \\
\text { Oil } 2 \% \text { w/v }\end{array}$} & \multirow{2}{*}{$\begin{array}{c}\text { Cyclohexanol } \\
0.025 \% \mathrm{w} / \mathrm{v}\end{array}$} \\
\hline Isolates & Test & & & & & & \\
\hline \multirow{2}{*}{ M2H2 1} & OST (cm) & $0.6 \pm 0$ & $8.9 \pm 0.9$ & $3.2 \pm 0.7$ & $4.6 \pm 0.5$ & $3.1 \pm 0.1$ & $1.8 \pm 0.3$ \\
\hline & $\mathrm{EA}\left(\mathrm{EU} \mathrm{\textrm {ml } ^ { - 1 } )}\right.$ & $10 \pm 2$ & $67 \pm 10$ & $169 \pm 16$ & $61 \pm 2$ & $75 \pm 6$ & $10 \pm 1$ \\
\hline \multirow{2}{*}{ M2H2 3} & OST (cm) & $1.9 \pm 0.3$ & $4.5 \pm 0.2$ & $4.4 \pm 0.7$ & $3.1 \pm 0.2$ & $4.8 \pm 1.1$ & 0 \\
\hline & $\mathrm{EA}\left(\mathrm{EU} \mathrm{m \textrm {m } ^ { - 1 } )}\right.$ & $39 \pm 8$ & $94 \pm 9$ & $86 \pm 7$ & $47 \pm 4$ & $265 \pm 5$ & $34 \pm 1$ \\
\hline \multirow{2}{*}{ M2H2 4} & OST (cm) & $7.3 \pm 0.6$ & $5.5 \pm 0.8$ & $5.8 \pm 0.5$ & $3.6 \pm 0.7$ & $8.2 \pm 0$ & 0 \\
\hline & $\mathrm{EA}\left(\mathrm{EU} \mathrm{m \textrm {m } ^ { - 1 } )}\right.$ & $54 \pm 10$ & $43 \pm 6$ & $68 \pm 0.3$ & $31 \pm 4$ & $189 \pm 7$ & $42 \pm 3$ \\
\hline \multirow{2}{*}{ M2H2 7} & OST (cm) & $5.6 \pm 0.8$ & $3.7 \pm 0$ & $4 \pm 0.4$ & $4.8 \pm 0.5$ & $5.1 \pm 0.8$ & 0 \\
\hline & EA $\left(E U ~ m l^{-1}\right)$ & $30 \pm 4$ & $44 \pm 7$ & $90 \pm 17$ & $12 \pm 0$ & $410 \pm 4$ & $15 \pm 2$ \\
\hline \multirow{2}{*}{ M2H2 8} & OST (cm) & $4.5 \pm 0.9$ & $6 \pm 1.2$ & $5.7 \pm 0.8$ & $5.8 \pm 0.1$ & $7.6 \pm 0.2$ & 0 \\
\hline & $\mathrm{EA}\left(\mathrm{EU} \mathrm{\textrm {ml } ^ { - 1 } )}\right.$ & $0.53 \pm 0$ & $66 \pm 9$ & $51 \pm 5$ & $44 \pm 2$ & $169 \pm 16$ & $21 \pm 2$ \\
\hline \multirow{2}{*}{ M2H2 10} & OST (cm) & $3.7 \pm 0.5$ & $7.2 \pm 0.4$ & $6 \pm 0.6$ & $8.2 \pm 1.1$ & $7.7 \pm 0.9$ & 0 \\
\hline & $\mathrm{EA}\left(\mathrm{EU} \mathrm{\textrm {ml } ^ { - 1 } )}\right.$ & $2 \pm 0$ & $39 \pm 1$ & $48 \pm 7$ & $29 \pm 7$ & $92 \pm 3$ & $38 \pm 5$ \\
\hline \multirow{2}{*}{ M2H2 14} & OST (cm) & $8.9 \pm 8$ & $11.3 \pm 0.3$ & $9.3 \pm 0.4$ & $9.8 \pm 0.5$ & $7 \pm 1$ & 0 \\
\hline & EA (EU ml-1) & $13 \pm 1$ & $78 \pm 8$ & $24 \pm 3$ & $338 \pm 53$ & $31 \pm 4$ & $33 \pm 4$ \\
\hline \multirow{2}{*}{ M2H2 15} & OST (cm) & $2.4 \pm 0$ & $7.6 \pm 0.2$ & $5.8 \pm 0.7$ & $9.8 \pm 0.1$ & $6.5 \pm 1.1$ & 0 \\
\hline & $\mathrm{EA}\left(\mathrm{EU} \mathrm{\textrm {ml } ^ { - 1 } )}\right.$ & $21 \pm 3$ & $62 \pm 5$ & $38 \pm 4$ & $356 \pm 33$ & $21 \pm 0.3$ & $17 \pm 3$ \\
\hline \multirow{2}{*}{ M2H2 16} & OST (cm) & 0 & $7.1 \pm 0.7$ & $6.4 \pm 0.9$ & $2.8 \pm 0$ & $6.7 \pm 0.4$ & 0 \\
\hline & EA (EU ml-1) & $23 \pm 2$ & $58 \pm 9$ & $38 \pm 3$ & $52 \pm 6$ & $16 \pm 1$ & $13 \pm 3$ \\
\hline \multirow{2}{*}{ M2H2 18} & OST (cm) & 0 & $8.5 \pm 0.3$ & $7.1 \pm 0.1$ & $5.9 \pm 1.3$ & $9.6 \pm 1.2$ & 0 \\
\hline & $\mathrm{EA}\left(\mathrm{EU} \mathrm{ml}^{-1}\right)$ & $2 \pm 0$ & $93 \pm 14$ & $33 \pm 6$ & $42 \pm 4$ & $17 \pm 4$ & $17 \pm 3$ \\
\hline
\end{tabular}

Table 2: The recorded biosurfactant activity according to oil spread test (OST) and emulsification assay (EA) using different substrates. Relevant isolates were incubated for 6 days at $35 \pm 2^{\circ} \mathrm{C}$. 
Citation: Hassan M, Essam T, Yassin AS, Salama A (2014) Screening of Bio-Surfactant Production Ability among Organic Pollutants Degrading Isolates Collected From Egyptian Environment. J Microb Biochem Technol 6: 195-201. doi:10.4172/1948-5948.1000143

\begin{tabular}{|c|c|c|c|c|c|c|c|c|c|c|}
\hline Isolate & $\begin{array}{c}\mathrm{M} 2 \mathrm{H} 2 \\
1\end{array}$ & $\begin{array}{c}\mathrm{M} 2 \mathrm{H} 2 \\
3\end{array}$ & $\begin{array}{l}\mathrm{M} 2 \mathrm{H} 2 \\
4\end{array}$ & $\begin{array}{l}\text { M2H2 } \\
7\end{array}$ & $\begin{array}{l}\mathrm{M} 2 \mathrm{H} 2 \\
8\end{array}$ & $\begin{array}{l}\text { M2H2 } \\
10\end{array}$ & $\begin{array}{l}\mathrm{M} 2 \mathrm{H} 2 \\
14\end{array}$ & $\begin{array}{l}\text { M2H2 } \\
15\end{array}$ & $\begin{array}{l}\text { M2H2 } \\
16\end{array}$ & $\begin{array}{l}\text { M2H2 } \\
18\end{array}$ \\
\hline \multicolumn{11}{|l|}{ Test } \\
\hline Motility & + & - & - & - & - & - & + & + & - & - \\
\hline Oxidase & + & - & - & - & - & - & + & + & - & - \\
\hline API 20NE & Burkholderia spp. & $\mathrm{N} / \mathrm{A}$ & N/A & $\mathrm{N} / \mathrm{A}$ & N/A & N/A & Pseudomonas & Burkholderia spp. & N/A & N/A \\
\hline API 20E & $\mathrm{N} / \mathrm{A}$ & \multicolumn{5}{|c|}{ Klebsiella spp. } & $\mathrm{N} / \mathrm{A}$ & $\mathrm{N} / \mathrm{A}$ & Klebsiella spp. & Pantoea spp. \\
\hline 16S rRNA & $\begin{array}{l}\text { Pseudomonas } \\
\text { (KJ123699) }\end{array}$ & $\begin{array}{c}\begin{array}{c}\text { Citrobacter } \\
\text { (KJ123700) }\end{array} \\
\end{array}$ & $\begin{array}{c}\text { Klebsiella } \\
\text { (KF384449.1) }\end{array}$ & \begin{tabular}{|c|} 
Klebsiella \\
(KF384450.1)
\end{tabular} & $\begin{array}{c}\text { Klebsiella } \\
\text { (KF384451.1) }\end{array}$ & $\begin{array}{c}\text { Klebsiella } \\
\text { (KF384452.1) }\end{array}$ & $\begin{array}{c}\text { Klebsiella } \\
\text { (KF384453.1) }\end{array}$ & $\begin{array}{l}\text { Pseudomonas } \\
\text { (KF384454.1) }\end{array}$ & $\begin{array}{c}\text { Klebsiella } \\
\text { (KJ123701) }\end{array}$ & $\begin{array}{c}\text { Klebsiella } \\
\text { (KJ123702) }\end{array}$ \\
\hline
\end{tabular}

Table 3: Summary of morphological, biochemical and molecular identification of the isolated bacterial strains (N/A means not applied).
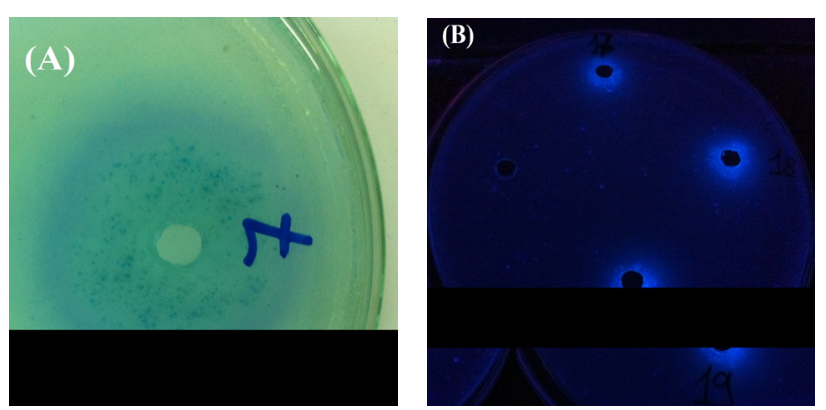

Figure 1: TBlue agar plates (CTAB agar plates) showing dark blue haloes indicating the production of anionic surfactants. Ten micro liters of the inoculum were added into each well, plates were incubated for $48 \mathrm{~h}$ at $37^{\circ} \mathrm{C}$ and then stored in the refrigerator for $24 \mathrm{~h}$. Dark blue haloes were then detected using normal light condition (A) and UV transilluminator (B).

spp., while isolates $\mathrm{M} 2 \mathrm{H} 2 \mathrm{1}, \mathrm{M} 2 \mathrm{H} 214$ and $\mathrm{M} 2 \mathrm{H} 215$ belonged to Pseudomonas spp. (Table 3).

\section{Biodegradation and metabolic versatility}

The biodegradation versatility of the ten isolates was investigated against aliphatic hydrocarbons (hexane, decane, dodecane and hexadecane), aromatic hydrocarbons (Benzene, toluene, xylene, pyridine, phenol, cresol, salicylate and naphthalene) and cyclic hydrocarbons (cyclohexanol). All isolates were able to tolerate and metabolize hexadecane, benzene, cyclohexanol and cresol (Table 1). However, none of the isolates was able to grow on either dodecane or naphthalene (Table 1).

\section{Screening of biosurfactant production ability of biodegrading isolates}

Preliminary screening of the isolates for biosurfactant production was carried out using paraffin oil (mineral oil) as the sole substrate. Eventually, the biosurfactants production was investigated using different types of substrates; vegetable oils, organic solvents and organic pollutant (Table 2). No biosurfactant activity was observed when using any of the organic solvents (hexane, benzene or xylene) as sole carbon source (data not shown). Statistical analysis using two ways ANOVA revealed a significant difference in biosurfactant activity with different substrates and isolates (Table 2). The highest biosurfactant activities were recorded when vegetable oils were used and especially, Coconut oil (Table 2) and therefore it was selected as a substrate model for further experimental work. All isolates showed dark blue haloes in the CTAB agar plates (Figure 1) indicating that the produced biosurfactants were anionic surfactants.

\section{Investigation of the dual effect "biodegradation coupled with biosurfactant production"}

Four isolates (M2H2 1, M2H2 3, M2H2 8 and $\mathrm{M} 2 \mathrm{H} 2$ 14) were selected for testing the biosurfactants production ability in the presence of an organic pollutant as sole substrate and in combination with coconut oil. Addition of any of the tested organic pollutants had no significant effect on the biosurfactants production. Interestingly, biosurfactant activity was significantly reduced (by more than $70 \%$ ) when either phenol or cyclohexanol were used as sole carbon source (Figure 2). Among these four isolates, two isolates (M2H2 1 and $\mathrm{M} 2 \mathrm{H} 2$ 14) were selected for further studies due to their recorded highest biodegradation capacity.

The dual effect (biosurfactant production and biodegradation)

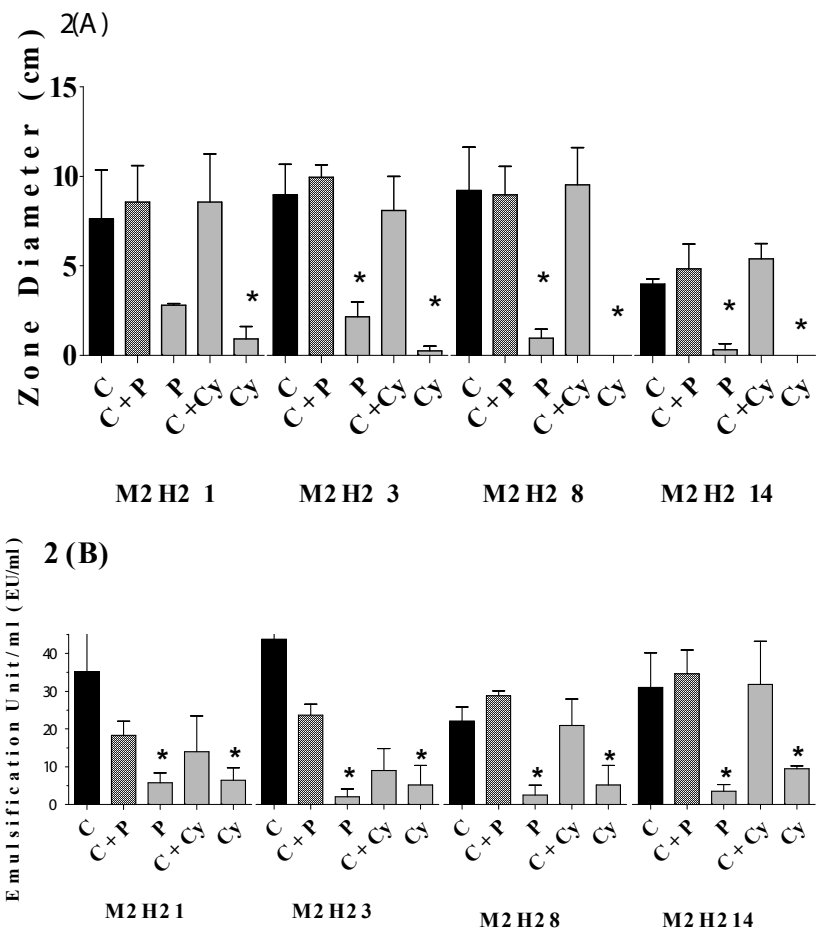

Figure 2: The recorded biosurfactant activity by the most relevant four isolates in the presence of $(C)$ coconut oil $2 \%,(P)$ phenol $0.01 \%$ and/or $(C y)$ cyclohexanol $0.025 \%$ or combinations thereof. The isolates were incubated for 6 days at $35 \pm 2{ }^{\circ} \mathrm{C}$ and agitation rate $180 \mathrm{rpm}$. *: Indicates significant difference from control column (Coconut oil $2 \%$ ) at $P$-value $<0.05$ (one way ANOVA test). The biosurfactants activity was expressed as zone diameter based on the oil spread test $(A)$ and Emulsification unit $\mathrm{ml}^{-1}$ based on the emulsification assay (B). 


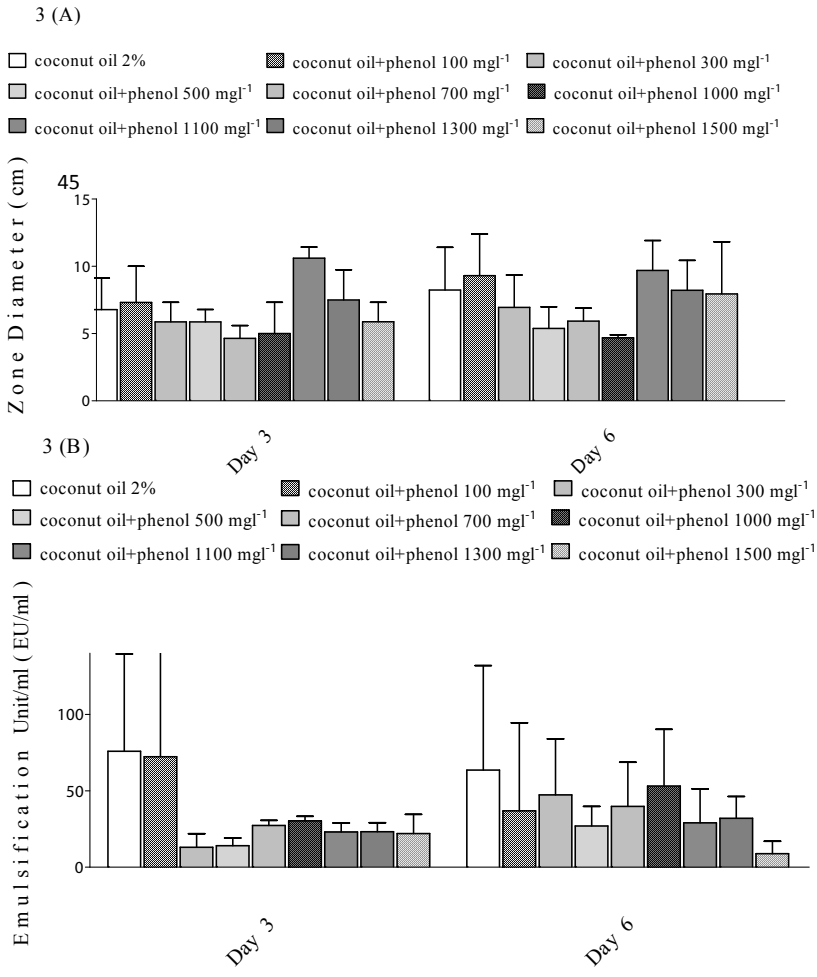

Figure 3: The recorded biosurfactant activity by isolate $\mathrm{M} 2 \mathrm{H} 21$ using coconut oil $2 \% \mathrm{w} / \mathrm{v}$ with increasing concentrations of phenol $\left(100-1500 \mathrm{mgl}^{-1}\right)$. The isolate was incubated for 6 days at $35 \pm 2^{\circ} \mathrm{C}$ and agitation rate $180 \mathrm{rpm}$. The biosurfactants activity was expressed as (zone diameter) based on the oil spread test $(A)$ and Emulsification unit $\mathrm{ml}^{-1}$ based on the emulsification assay (B).

was further studied using coconut oil $2 \% \mathrm{w} / \mathrm{v}$ with adding increasing concentrations of phenol (100-1700 $\left.\mathrm{mgl}^{-1}\right)$. The two isolates M2H2 1 and $\mathrm{M} 2 \mathrm{H} 214$ retained their biosurfactant productivity (Figures 3 and 4) -no significant reduction- when increasing concentrations of phenol were added up to 1500 and $1300 \mathrm{mg} \mathrm{l}^{-1}$, respectively. Nevertheless, phenol biodegradation was almost completely inhibited by both isolates (Data not shown).

Consequently, an induction procedure was adopted where $500 \mathrm{mg}$ $\mathrm{l}^{-1}$ of phenol was used to establish enough biomass prior the addition of additional $500 \mathrm{mg} \mathrm{l}^{-1}$ phenol and coconut oil $2 \% \mathrm{w} / \mathrm{v}$. Statistical analysis using paired t-test showed that for isolate $\mathrm{M} 2 \mathrm{H} 2 \mathrm{1}$, there was no significant difference in biosurfactant activity either with or without induction. However, phenol removal percentage differed significantly from $2 \%$ to $66 \%$ when using the induction regimen (Figure 5). A similar pattern was observed with isolate $\mathrm{M} 2 \mathrm{H} 214$, where the phenol biodegradation was enhanced by the induction, however, statistical analysis using paired $t$ test showed insignificant difference with and without induction (Figure 5).

\section{Discussion}

Molecular identification of the ten isolates revealed that they belong to three genera; Klebsiella (6), Pseudomonas (3) and Citrobacter (1). These three genera, in particular, possess interesting potential in term of both biodegradation and biosurfactants production [22-27]. For instance, members of Pseudomonas genus are well recognized for their capability of both degrading aromatic compounds especially phenol
[25,27] and biosurfactant production mainly rhamnolipids [24,26]. As for Klebsiella genus, recent studies have reported the isolation of several Klebsiella species with diverse biodegradation ability $[23,28]$. Other studies were likewise concerned with characterization of the biosurfactant produced $[22,29]$.

In this study, no biosurfactant activity was observed with the organic solvents used and the lowest biosurfactant productivity was observed when organic pollutants were used as sole carbon source. On the other hand, the use of vegetable oils (either as sole carbon source or mixed with organic pollutant) was always accompanied with higher production of biosurfactants. Several studies have reported similar patterns $[30,31]$, which could be attributed to the high organic and nutrient content of the vegetable oils [32]. Concurrently, this may be also according to the concentration of the used substrate which in turn affects stoichiometric requirement for high productivity [33].

Interestingly, although the toxicity of the pollutants is among the effects that should be taken in consideration [27], the addition of the selected pollutants had no significant effect on the biosurfactants production. Consequently, the relevance of using high tolerant and biodegrading isolates should be explored. Based on the results obtained, coconut oil was selected as a substrate model for further experimental work. This is due to the high biosurfactant activity recorded when used as substrate in addition to the ease of the downstream processes as this oil tends to solidify as separate layer at room temperature.

Biodegradation combined with biosurfactant production was investigated in the presence of a model of organic pollutant (phenol). Isolates tolerated high phenol concentrations in the presence of oil with no significant effect on biosurfactant productivity. However, the phenol biodegradation property was significantly diminished. Biodegradation

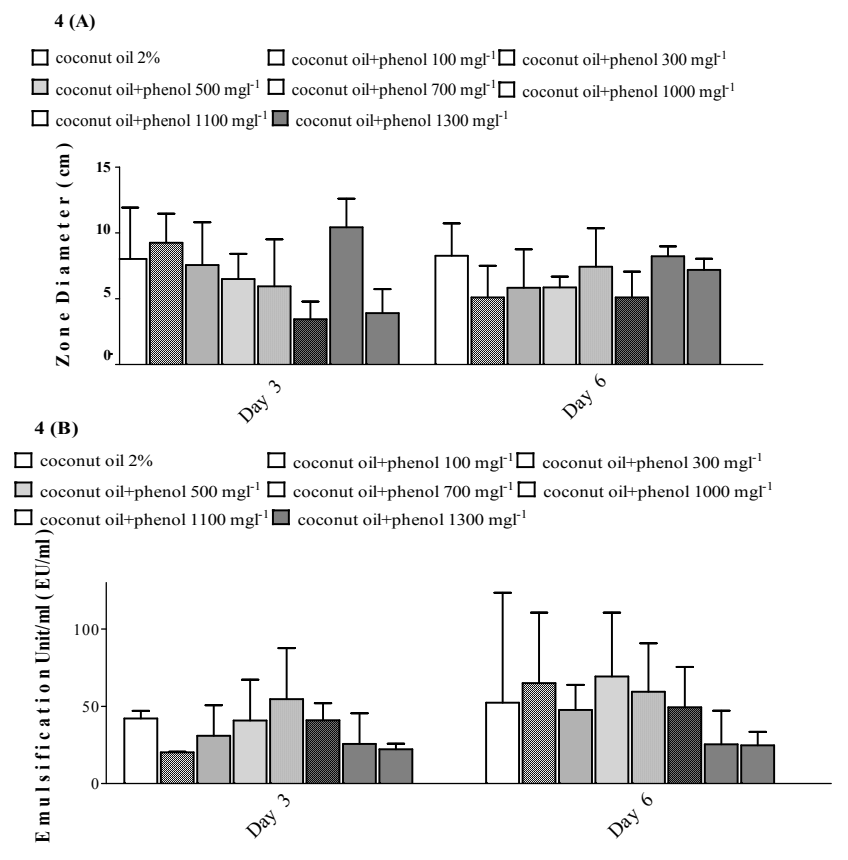

Figure 4: The recorded biosurfactant activity by isolate $\mathrm{M} 2 \mathrm{H} 214$ using coconut oil $2 \% \mathrm{w} / \mathrm{v}$ with increasing concentrations of phenol $\left(100-1300 \mathrm{mgl}^{-1}\right)$. The isolate was incubated for 6 days at $35 \pm 2^{\circ} \mathrm{C}$ and agitation rate $180 \mathrm{rpm}$. The biosurfactants activity was expressed as (zone diameter) based on the oil spread test $(A)$ and Emulsification unit $\mathrm{ml}^{-1}$ based on the emulsification assay (B) 
Citation: Hassan M, Essam T, Yassin AS, Salama A (2014) Screening of Bio-Surfactant Production Ability among Organic Pollutants Degrading Isolates Collected From Egyptian Environment. J Microb Biochem Technol 6: 195-201. doi:10.4172/1948-5948.1000143
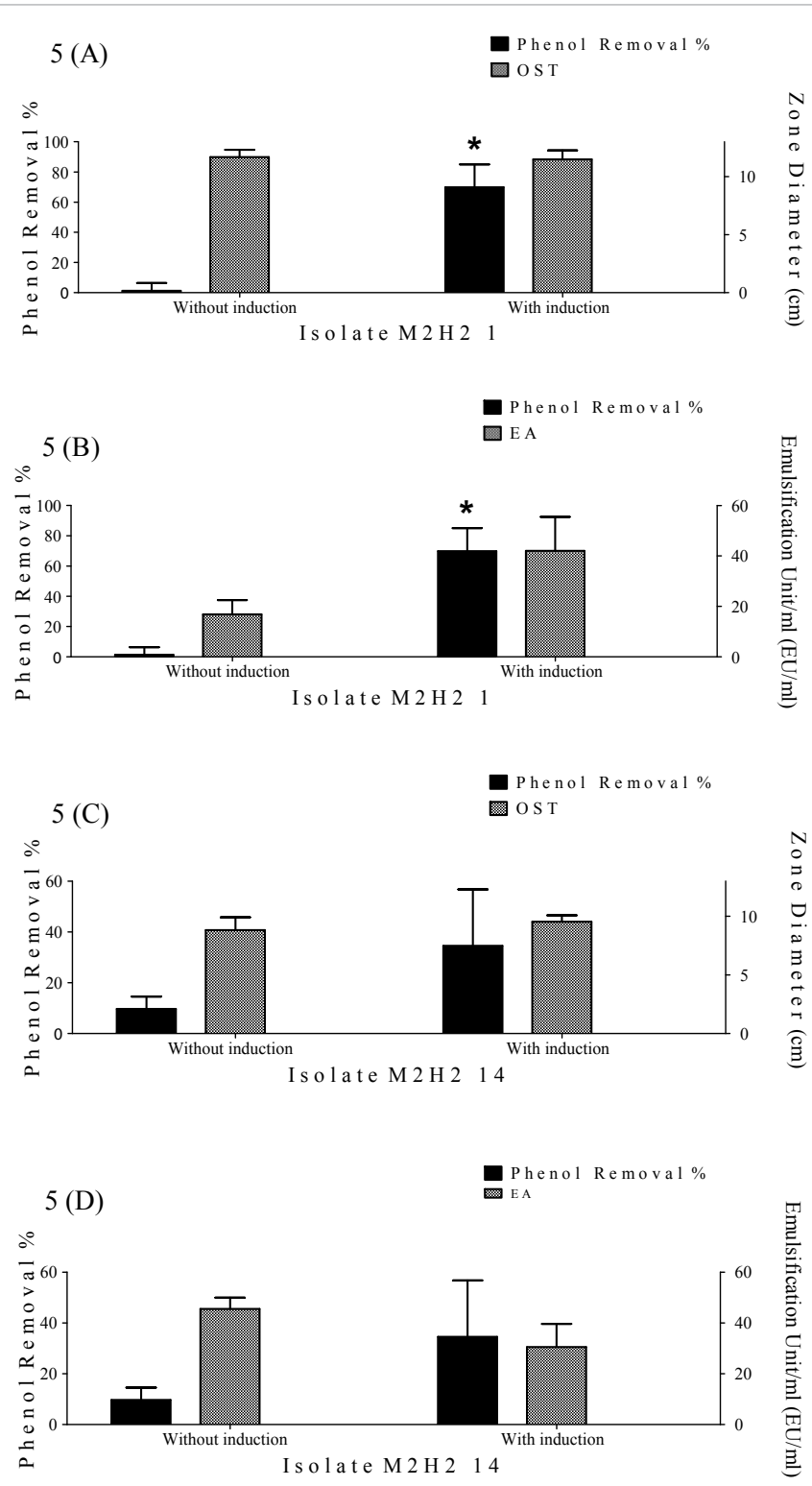

Figure 5: Comparing biosurfactant activity and phenol removal percent recorded by isolate $\mathrm{M} 2 \mathrm{H} 21(\mathrm{~A} \& \mathrm{~B})$ and isolate $\mathrm{M} 2 \mathrm{H} 214(\mathrm{C} \& \mathrm{D})$ with and without induction regimen. Isolates were grown at $35 \pm 2^{\circ} \mathrm{C}$ with agitation $(180$ $\mathrm{rpm})$ for 6 days on MSM media supplied with coconut oil $(2 \% \mathrm{w} / \mathrm{v})$ together with phenol $\left(500 \mathrm{mgl}^{-1}\right)$. Induction regimen was conducted using $500 \mathrm{mg} \mathrm{l}^{-1}$ of phenol to establish enough biomass prior to the addition of additional phenol $\left(500 \mathrm{mgl}^{-1}\right)$ and coconut oil $(2 \% \mathrm{w} / \mathrm{v}){ }^{*}$ : indicates significant difference at $\mathrm{P}$-value $<0.05$ (paired $t$ test).

of phenol is mainly aerobic and required sufficient oxygen concentration and adequate fast mass transfer [34,35], especially at the initial stages during the formation of enough biomass and the essential enzymatic activities. This might explain the recorded deterioration of the phenol biodegradation when the coconut oil was added, where the lack of oxygen could have a limiting effect on phenol biodegradation [34]. This observation was confirmed when an induction regimen was performed where the biomass was allowed initially to degrade $500 \mathrm{mg} \mathrm{l}^{-1}$ of phenol then the oil and more $500 \mathrm{mg} \mathrm{l}^{-1}$ phenol were further added. Indeed, the initial induction allowed the building of enough biomass and induced the necessary enzymatic activities [36].

\section{Conclusion}

A total of ten biodegrading bacterial isolates with relevant biosurfactant production ability were characterized. The presence of increasing concentrations of organic pollutant (phenol) had no effect on biosurfactant production by these strains. Two isolates had potential dual effect; pollutants biodegradation and biosurfactants production. The present study provides a promising strategy and candidates for integrated and effective bioremediation purposes.

\section{Acknowledgements}

Mr. Mohamed Habib, teaching assistant, Department of Microbiology and Immunology, Faculty of Pharmacy, Cairo University is especially acknowledged for his kind assistance in the initial screening approach of the used isolates in the present study.

\section{References}

1. Morikawa M, Hirata Y, Imanaka T (2000) A study on the structure-function relationship of lipopeptide biosurfactants. Biochim Biophys Acta 1488: 211-218.

2. April TM, Foght JM, Currah RS (2000) Hydrocarbon-degrading filamentous fungi isolated from flare pit soils in northern and western Canada. Can $J$ Microbiol 46: 38-49.

3. Volkering F, Breure AM, Sterkenburg A, Andel JG (1992) Microbial degradation of polycyclic aromatic hydrocarbons: effect of substrate availability on bacterial growth kinetics. Applied Microbiology and Biotechnology 36: 548-552.

4. Annachhatre AP, Gheewala SH (1996) Biodegradation of chlorinated phenolic compounds. Biotechnol Adv 14: 35-56.

5. Banerjee I, Modak JM, Bandopadhyay K, Das D, Maiti BR (2001) Mathematical model for evaluation of mass transfer limitations in phenol biodegradation by immobilized Pseudomonas putida. J Biotechnol 87: 211-223.

6. Owsianiak M, Chrzanowski A, Szulc A, Staniewski J, Olszanowski A, et al. (2009) Biodegradation of diesel/biodiesel blends by a consortium of hydrocarbon degraders: effect of the type of blend and the addition of biosurfactants. Bioresour Technol 100: 1497-1500.

7. Zhang Y, Miller RM (1994) Effect of a Pseudomonas rhamnolipid biosurfactant on cell hydrophobicity and biodegradation of octadecane. Appl Environ Microbiol 60: 2101-2106.

8. Liu ZF, Zeng GM, Wang J, Zhong H, Ding Y, et al. (2010) Effects of monorhamnolipid and Tween 80 on the degradation of phenol by Candida tropicalis. Process Biochemistry 45: 805-809.

9. Reddy RM, Reddy PG, Seenayya G (1999) Enhanced production of thermostable ß-amylase and pullulanase in the presence of surfactants by Clostridium thermosulfurogenes SV2. Process Biochemistry 34: 87-92.

10. Ahuja SK, Ferreira GM, Moreira AR (2004) Production of an endoglucanase by the shipworm bacterium, Teredinobacter turnirae. J Ind Microbiol Biotechno 31: 41-47.

11. Helle SS, Duff SJ, Cooper DG (1993) Effect of surfactants on cellulose hydrolysis. Biotechnol Bioeng 42: 611-617.

12. Kiran GS, Hema TA, Gandhimathi R, Selvin J, Thomas TA, et al. (2009) Optimization and production of a biosurfactant from the sponge-associated marine fungus Aspergillus ustus MSF3. Colloids Surf B Biointerfaces 73: 250 256.

13. Das K, Mukherjee AK (2007) Crude petroleum-oil biodegradation efficiency of Bacillus subtilis and Pseudomonas aeruginosa strains isolated from a petroleum-oil contaminated soil from North-East India. Bioresour Technol 98 : 1339-1345.

14. Van Hamme JD, Singh A, Ward OP (2006) Physiological aspects. Part 1 in a series of papers devoted to surfactants in microbiology and biotechnology. Biotechnol Adv 24: 604-620.

15. Essam T, Amin MA, El Tayeb O, Mattiasson B, Guieysse B (2010) Kinetics and metabolic versatility of highly tolerant phenol degrading Alcaligenes strain TW1. J Hazard Mater 173: 783-788.

16. Gerhardt P (1994), Methods for general and molecular bacteriology. American Society for Microbiology. 
Citation: Hassan M, Essam T, Yassin AS, Salama A (2014) Screening of Bio-Surfactant Production Ability among Organic Pollutants Degrading Isolates Collected From Egyptian Environment. J Microb Biochem Technol 6: 195-201. doi:10.4172/1948-5948.1000143

17. Weisburg WG, Barns SM, Pelletier DA, Lane DJ (1991) 16S ribosomal DNA amplification for phylogenetic study. J Bacteriol 173: 697-703

18. Patil JR, Chopade BA (2001) Studies on bioemulsifier production by Acinetobacter strains isolated from healthy human skin. J Appl Microbiol 91 : 290-298.

19. Siegmund, I. and F. Wagner (1991) New method for detecting rhamnolipids excreted byPseudomonas species during growth on mineral agar. Biotechnology Techniques 5: 265-268.

20. Gunther NW 4th, Nuñez A, Fett W, Solaiman DK (2005) Production of rhamnolipids by Pseudomonas chlororaphis, a nonpathogenic bacterium. Appl Environ Microbiol 71: 2288-2293.

21. Pinzon NM, Ju LK (2009) Improved detection of rhamnolipid production using agar plates containing methylene blue and cetyltrimethylammonium bromide. Biotechnol Lett 31: 1583-1588.

22. Jamal P, Nawawi WMFW, Alam MZ (2012) Optimum Medium Components for Biosurfactant Production by Klebsiella pneumoniae WMF02 Utilizing Sludge Palm Oil as a Substrate. Australian Journal of Basic and Applied Sciences 6: 100-108.

23. Kadakol J, Kamanavalli C, Shouche $Y$ (2011) Biodegradation of Carbofuran phenol by free and immobilized cells of Klebsiella pneumoniae ATCC13883T. World Journal of Microbiology and Biotechnology 27: 25-29.

24. Raza ZA, Khalid ZM, Banat IM (2009) Characterization of rhamnolipids produced by a Pseudomonas aeruginosa mutant strain grown on waste oils. J Environ Sci Health A Tox Hazard Subst Environ Eng 44: 1367-1373.

25. Liu YJ, Nikolausz M, Wang XC (2009) Biodegradation and detoxication of phenol by using free and immobilized cells of Acinetobacter sp. XA05 and Sphingomonas sp. FG03. J Environ Sci Health A Tox Hazard Subst Environ Eng 44: 130-136

26. Perfumo A, Banat IM, Canganella F, Marchant R (2006) Rhamnolipid production by a novel thermophilic hydrocarbon-degrading Pseudomonas aeruginosa AP02-1. Appl Microbiol Biotechnol 72: 132-138.
27. Marrot B, Barrios-Martinez A, Moulin P, Roche N (2006) Biodegradation of high phenol concentration by activated sludge in an immersed membrane bioreactor. Biochemical Engineering Journal 30: 174-183.

28. Chaudhari AU, Kodam KM (2010) Biodegradation of thiocyanate using coculture of Klebsiella pneumoniae and Ralstonia sp. Appl Microbiol Biotechnol 85: 1167-1174

29. Lee SC, Lee SJ, Kim SH, Park IH, Lee YS, et al. (2008) Characterization of new biosurfactant produced by Klebsiella sp. Y6-1 isolated from waste soybean oil. Bioresour Technol 99: 2288-2292.

30. Pornsunthorntawee O, Wongpanit P, Rujiravanit R (2010) Rhamnolipid biosurfactants: production and their potential in environmental biotechnology. Adv Exp Med Biol 672: 211-221.

31. Robert M, Mercadé ME, Bosch MP, Parra JL, Espuny MJ, et al. (1989) Effect of the carbon source on biosurfactant production byPseudomonas aeruginosa 44T1. Biotechnology Letters 11: 871-874.

32. Raza ZA, Rehman A, Khan MS, Khalid ZM (2007) Improved production of biosurfactant by a Pseudomonas aeruginosa mutant using vegetable oil refinery wastes. Biodegradation 18: 115-121.

33. Müller RH, Rohwerder T, Harms H (2007) Carbon conversion efficiency and limits of productive bacterial degradation of methyl tert-butyl ether and related compounds. Appl Environ Microbiol 73: 1783-1791.

34. Melo JS, Kholi S, Patwardhan AW, D'Souza SF (2005) Effect of oxygen transfer limitations in phenol biodegradation. Process Biochemistry 40: 625-628.

35. Páca J, Komárková E, Prell A, Stiborová M, Sobotka M (2002) Kinetics of phenol oxidation by Candida tropicalis: effects of oxygen supply rate and nutrients on phenol inhibition. Folia Microbiol (Praha) 47: 701-707.

36. Guerin WF, Boyd SA (1995) Maintenance and induction of naphthalene degradation activity in Pseudomonas putida and an Alcaligenes sp. under different culture conditions. Appl Environ Microbiol 61: 4061-4068. 